\title{
Editorial
}

\section{Calling for Humanistic Scholarship in China}

\section{Anne S. Tsui ${ }^{1,2,3,4}$ and Liangding $\mathrm{Jia}^{5}$}

${ }^{1}$ Arizona State University, USA, ${ }^{2}$ Fudan University, China, ${ }^{3}$ Peking University, China, ${ }^{4}$ Shanghai fiao Tong University, China and ${ }^{5}$ Nanjing University, China

Scholarship refers to the formal and serious study of subjects such as medicine, physics, biology, history, philosophy, and business. Good scholarship demands that researchers apply rigorous scientific methods to find valid knowledge that can improve life, both human and nonhuman. Hence, scholarship and science share the common ideal of contributing to the development of a better society and a better world. Albert Einstein said, 'Concern for making life better for ordinary humans must be the chief objective of science' (Einstein qtd. in Isaacson, 2008: 374). Similarly, Oscar Handlin, one of the greatest contemporary historians, argued 'Scholarship has to prove its worth not on its own terms, but by its service to the nation and to the world' (Handlin qtd. in Boyer, 1996: 17). Clearly, scholarship, science, and the idea of 'humanism' are connected. In this editorial, we discuss the importance of humanistic scholarship - scholarship for the purpose of improving human welfare by focusing on the social outcomes of organizations - for business research and particularly for Chinese management research.

We begin by analyzing the current status of humanistic studies in general management research and then provide data on humanism-oriented research in Chinese management over the past thirty years. Results show a dramatic dominance of economic focus relative to human welfare focus, especially in the studies published in the Chinese journals. We conclude with a call for more research on humanism-related topics to counterbalance the dominant economic focus. Management and Organization Review (MOR) welcomes such papers.

\section{HUMANISM IN MANAGEMENT RESEARCH}

The term humanism has a deep philosophical, religious, and ethical foundation in the literature. This editorial is not the place to debate the proper definition of this term. We use it here simply to refer to respect for the dignity of humans and justice 
in decisions regarding the allocation of resources, opportunities, and rewards. We see a parallel in the concepts of humanism and compassion, which was the focus of the first author's Presidential address at the Academy of Management meeting in Boston. Compassion refers to

'an attitude toward other[s], either close others or strangers or all of humanity; containing feelings, cognitions, and behaviors that are focused on caring, concern, tenderness, and an orientation toward support, helping, and understanding the other[s], particularly when the other[s] is [are] perceived to be suffering or in need'. (Sprecher \& Fehr, 2005: 630)

Similar to compassion, humanism is a proactive orientation toward preserving or advancing the wellbeing of humans with or without involving suffering.

In Tsui's (2012) presidential address, she observed that increased suffering in our world is accompanied by corresponding increases in compassion, both at the individual and the corporate levels. She explained that Albert Einstein, Charles Darwin, Adam Smith, and other great scientists in physics, biology, and economics emphasized that science's grandest purpose is to improve the human condition in the short run and to ensure mankind's survival and sustainability in the long run. Thus, compassion or humanism is important in both science and practice. Although Nobel Laureate Milton Friedman (1970) said that corporations should leave charity or philanthropy (different forms of compassion or humanism) to individuals, many for-profit corporations are engaging in compassionate activities (Tsui, 2013).

At the same time, management scholars are becoming increasingly aware and concerned that management research has ignored this important objective of science and has focused instead on publishing in a few select journals to avoid perishing in the promotion and tenure process (e.g., Walsh, 2011). Tsui lamented the irony in current management scholarship, 'While corporations are moving from pure profit motives toward social responsibility, academic institutions, which are supposed to contribute to humanity's short-term well-being and long-term sustainability, are deviating from their social objective toward self-serving behaviors'. (2013: 177).

The lack of attention to humanism is evident in the contents of management studies. As Walsh, Weber, and Margolis (2003) pointed out, the Journal of the Academy of Management (later renamed Academy of Management Journal) founded in 1958, originally aimed to serve the public interest by publishing research designed to help accomplish the economic and social objectives of an industrialized society. The preface to the first issue of the Journal of the Academy of Management stated,

'the general objective of the Academy shall be therefore to foster a philosophy of management that will make possible the accomplishment of the economic and social objectives of an industrial society with increasing efficiency and effective- 
ness: the public's interests must be paramount in any such philosophy, but adequate consideration must be given to the legitimate interests of capital and labor ... (Editor, 1958: 5-6)

The research record, however, reveals that the Academy of Management Foumal has failed to meet those goals. An analysis of 1,738 empirical articles published from 1958 to 2000 led to the conclusion that, 'scholarship in our field has pursued society's economic objectives much more than it has its social ones' (Walsh et al., 2003: 859).

Does the dominant focus on economic performance apply to management research in the Chinese context? After all, China is a socialist state that emphasizes equality among all members of society and, until recently, disdains private property and capitalism. To answer that question, we adopted Walsh et al.'s (2003) method and analyzed articles published in the top English and Chinese language journals, focusing on studies that use Chinese samples.

\section{Humanism in Chinese Management Research}

First, we used the data from the Jia, You, and Du (2012) study that included articles related to Chinese contexts published in six leading English journals in the management and organization research fields: Administrative Science Quarterly, Academy of Management Journal, Strategic Management Joumal, Journal of Applied Psychology, Organization Science, and Foumal of International Business Studies. The first article related to the Chinese context appeared in 1985, and through 2012, the six journals published 312 such articles.

Our second sample includes articles published in $M O R$, which primarily aims to promote 'scholarly studies of organization and management of firms in the Chinese context'. We identified 134 articles, excluding editorials and commentaries, during the eight years from the time it was launched in 2005 through 2012.

The third sample includes articles published in three leading management and organization journals from mainland China: Management World [管理世界], Nankai Business Reviere [南开管理评论], and China Industrial Economics [中国工业经济], which was the earliest journal launched in 1983. Using the same selection criteria we used for the six top journals and for $M O R$, we found 2,388 articles published in thirty years, from 1983 to 2012 . Table 1 shows the number of articles in each of the ten journals each year.

Similar to the procedures used by Walsh et al. (2003), we analyzed each article for its core focus or phenomenon being explained and its primary disciplinary perspective. We also coded the level of analysis.

Core focus. We coded the dependent variables in the empirical articles $(97 \%$ for the six top English journals, $57 \%$ for $M O R$ articles, and $45 \%$ for the three top Chinese journals), or the key constructs being explained in the conceptual articles for their 


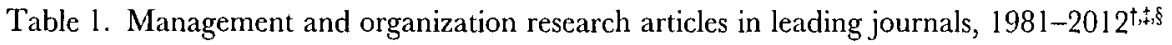

\begin{tabular}{|c|c|c|c|c|c|c|c|c|c|c|c|c|}
\hline & \multicolumn{4}{|c|}{$\begin{array}{l}\text { Three Chinese Journals } \\
\text { in Mainland China }\end{array}$} & \multicolumn{7}{|c|}{ Six English Journals } & \multirow[b]{2}{*}{$M O R$} \\
\hline & $M W$ & NBR & CIE & Subtotal & $A M \mathcal{J}$ & $A S Q$ & $\exists A P$ & $J I B S$ & OrgS $c i$ & $S M 7$ & Subtotal & \\
\hline 1983 & & & 1 & 1 & & & & & & & & \\
\hline 1984 & & & 1 & 1 & & & & & & & & \\
\hline 1985 & 7 & & 10 & 17 & & 1 & & & & & 1 & \\
\hline 1986 & 16 & & 28 & 44 & & & 1 & & & & 1 & \\
\hline 1987 & 14 & & 10 & 24 & 1 & & & 1 & & & 2 & \\
\hline 1988 & 24 & & 19 & 43 & & & & & & & & \\
\hline 1989 & 22 & & 16 & 38 & & 1 & & & & & 1 & \\
\hline 1990 & 16 & & 8 & 24 & & & & & & & & \\
\hline 1991 & 16 & & 20 & 36 & & & 1 & 1 & & & 2 & \\
\hline 1992 & 35 & 1 & 28 & 64 & & 1 & 1 & & & 1 & 3 & \\
\hline 1993 & 11 & 6 & 30 & 47 & 1 & & 1 & 2 & & & 4 & \\
\hline 1994 & 21 & 5 & 27 & 53 & 1 & 1 & & 1 & & 1 & 4 & \\
\hline 1995 & 19 & 3 & 35 & 57 & 3 & & & 1 & & & 4 & \\
\hline 1996 & 37 & 2 & 26 & 65 & 2 & 1 & & 3 & 1 & & 7 & \\
\hline 1997 & 26 & 2 & 26 & 54 & & 1 & & 2 & & 1 & 4 & \\
\hline 1998 & 20 & 4 & 27 & 51 & & & 2 & 5 & 2 & & 9 & \\
\hline 1999 & 22 & 27 & 35 & 84 & 1 & & & 4 & & 2 & 7 & \\
\hline 2000 & 28 & 16 & 29 & 73 & 5 & & 1 & 4 & & & 10 & \\
\hline 2001 & 32 & 30 & 27 & 89 & 1 & 1 & 2 & 6 & & 3 & 13 & \\
\hline 2002 & 50 & 41 & 34 & 125 & 3 & & 1 & 9 & 2 & 4 & 19 & \\
\hline 2003 & 48 & 35 & 31 & 114 & 2 & & & 5 & 2 & 4 & 13 & \\
\hline 2004 & 54 & 34 & 43 & 131 & 1 & & 2 & 3 & 9 & 3 & 18 & \\
\hline 2005 & 48 & 37 & 46 & 131 & 3 & 1 & 2 & 5 & 1 & 4 & 16 & 16 \\
\hline 2006 & 53 & 36 & 46 & 135 & & & 1 & 8 & 2 & 1 & 12 & 14 \\
\hline 2007 & 52 & 38 & 30 & 120 & 6 & 1 & 7 & 15 & & 3 & 32 & 14 \\
\hline 2008 & 60 & 31 & 43 & 134 & 1 & & l & 13 & 3 & 8 & 26 & 12 \\
\hline 2009 & 59 & 41 & 26 & 126 & 3 & & 4 & 9 & 3 & 7 & 26 & 18 \\
\hline 2010 & 64 & 44 & 48 & 156 & 4 & 2 & 6 & 21 & & 7 & 40 & 17 \\
\hline 2011 & 59 & 65 & 78 & 202 & 3 & & 10 & 4 & 1 & 4 & 22 & 22 \\
\hline 2012 & 45 & 34 & 70 & 149 & 4 & I & 4 & 6 & & 1 & 16 & 21 \\
\hline Total & 958 & 532 & 898 & 2,388 & 45 & 12 & 47 & 128 & 26 & 54 & 312 & 134 \\
\hline
\end{tabular}

Notes:

${ }^{\dagger}$ MW=Management World (管理世界); NBR=Nankai Business Review (南开管理评论); CIE = China Industrial Economics (中国工业经济); $A S Q=$ Administrative Science Quarterly; AMJ = Academy of Management Joumal; SMIJ = Strategic Management Joumal; $J A P=$ Joumal of Applied Psychology; OrgSci= Organization Science; 7 IBS = Joumal of International Business Studies; MOR = Management and Organization Review.

$\$$ Management World launched in 1985; Nankai Business Review renamed in 1998 from Intemational Trade Research which launched in 1992; China Industrial Economics launched in 1983; Management and Organization Review launched in 2005. ${ }^{\S}$ Administrative Science Quarterly published the first article related to Chinese contexts in 1985.

focus on economic performance or human welfare. Following Walsh et al. (2003), economic performance included efficiency, productivity, and market values or returns. Human welfare included health, satisfaction, justice, and social responsibility. Articles with double foci appeared in $6 \%$ of the English journals, $2 \%$ of the 
MOR articles, and $2 \%$ of the Chinese journals, and were double-counted in the analyses. Job growth could have either an economic or a social objective and we excluded such indicators due to its unclear meaning.

Level of analysis. We treated a focus on individuals and groups as the individual level of analysis. Focuses on firms and inter-firm linkages, whether vertical or horizontal, were counted at the organizational level. Focuses on industry, region, institutions, and the public-at-large were classified at the society level of analysis. Some articles involved more than one level, but most were at a single level $191 \%$ for six top English journals, $94 \%$ for $M O R$, and $92 \%$ for three top Chinese journals). Articles with multiple levels were multiple-counted.

Disciplinary perspective. Walsh et al. (2003) identified disciplinary perspectives by observing which journals the authors cited in their articles. Chinese journals use different citation sources than English journals do, so we coded all the articles in all three journal-samples for their primary theoretical perspective. If the research employed the theoretical perspectives of social exchange, social cognition, social identity, equity theory, or motivation theory to explain the core phenomenon, we considered the work to be based on the psychology discipline. If the research employed institutional theory, resource dependence theory, social capital theory, social structure perspective, or population theory to explain the core phenomenon, we coded the article as belonging to the sociology discipline. If the research employed transaction cost theory, resource-based view, industrial organization perspective, scale and scope economy, game theory, capital asset pricing model, agency theory, property theory, or contract theory, we considered it to have an economics perspective. We multiple-counted articles that used more than one perspective: 14\% of the English articles, 13\% of the MOR articles, and 10\% of the Chinese articles.

Coding reliability. We took several steps to ensure coding reliability. First, three research assistants independently coded 150 randomly selected articles, 100 from three Chinese journals, and 50 from seven English journals. After discussing the results, we improved the coding scheme, which the three assistants used to code independently another randomly selected 150 articles (100 from Chinese and 50 from English journals). The three coders showed $91 \%$ agreement on human welfare focus, $90 \%$ on economic performance focus, $94 \%$ on economics perspective, $96 \%$ on sociology perspective, $98 \%$ on psychology perspective, $93 \%$ on individual level, $90 \%$ on organizational level, and $93 \%$ on society level. After establishing adequate reliability, we randomly distributed the remaining articles equally to each coder.

Results. Figure 1 shows the results for the economic performance versus human welfare focus for the articles in the top six English journals, for the three levels 
Figure 1. Human welfare and performance focus in six leading English journals (a five-year moving average) - all three levels combined

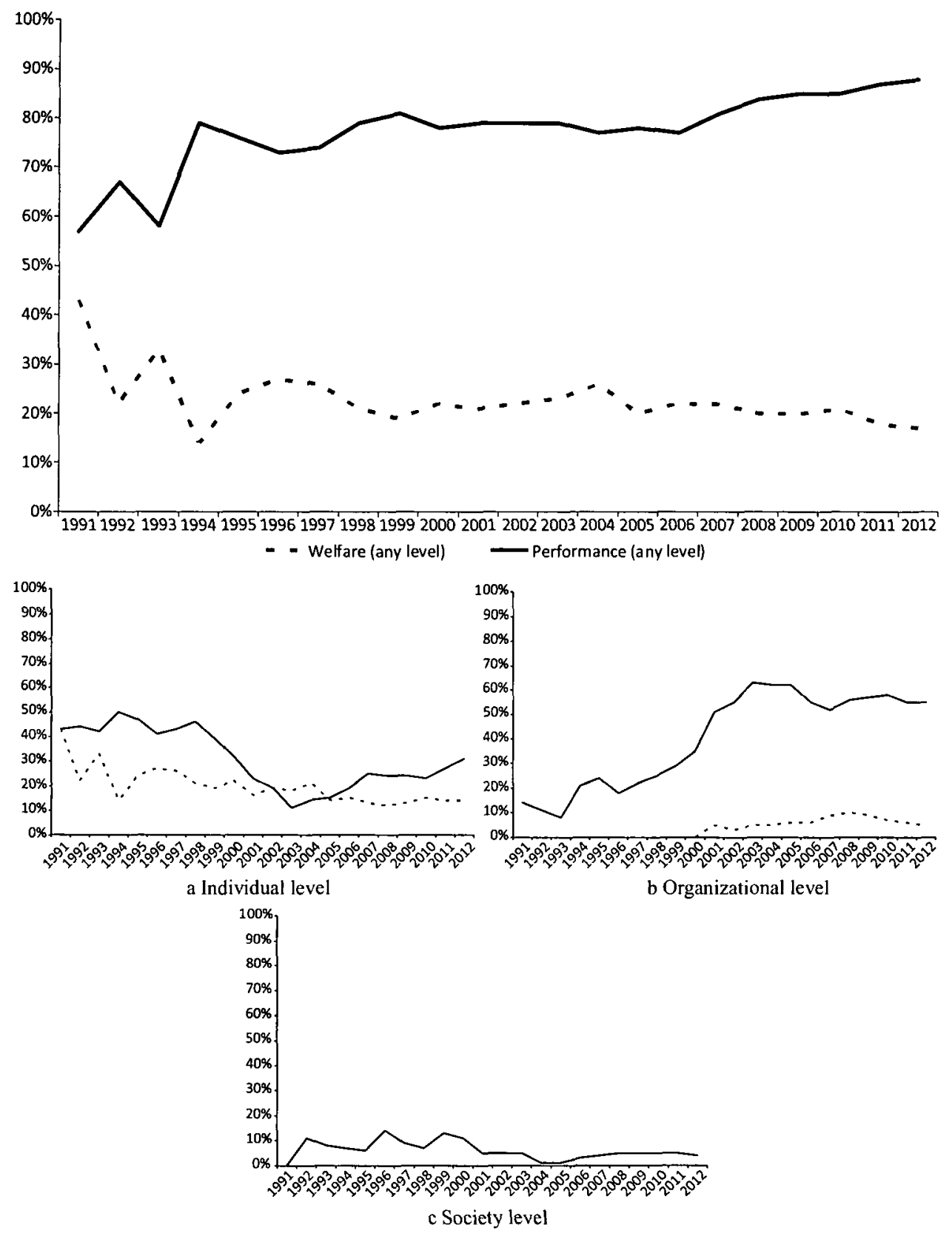

combined, and separately for individual, firm, and society levels (Figures la, 1b, and 1c). Figure 2 shows the results for the articles in MOR, and Figure 3 shows the results for the articles in the three Chinese journals. These three figures show the dominance of economic performance focus over human welfare focus in the research published in all three journal-samples. There are some differences in the 
Figure 2. Human welfare and performance focus in Management and Organization Review (a three-year moving average) - all three levels combined

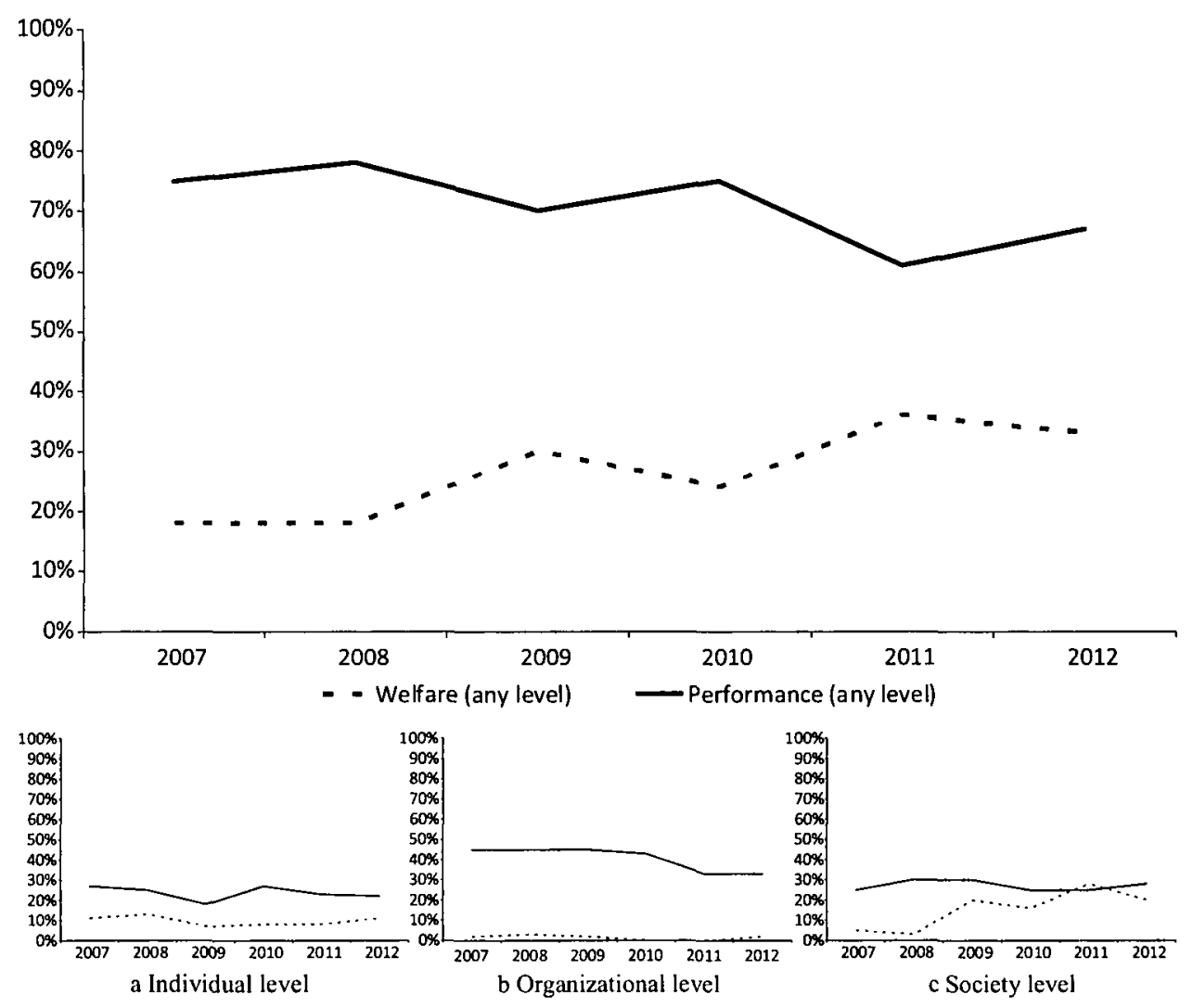

trends over time. In the leading six English journals, economic performance focus increased from $57 \%$ in 1991 to $88 \%$ in 2012 , while the focus on human welfare decreased from $43 \%$ in 1991 to $17 \%$ in 2012 . In the three Chinese journals, economic performance focus persisted over the thirty years at above $90 \%$ while human welfare focus has a small upward trend from $5 \%$ in 1987 to slightly above $10 \%$ in 2012. In MOR, there is a slight decline in economic performance focus (from $76 \%$ in 2005 to $68 \%$ in 2012), and a slight increase in human welfare focus (from $20 \%$ to $30 \%$ ).

The results are quite consistent with Walsh et al. (2003) in that most management studies focused on economic performance at all levels, but especially at the organizational level. Table 2 compares the results across the three journal-samples for the three levels of analysis and the three levels combined. The three Chinese journals showed the biggest difference from the other two journal-samples, with $94 \%$ of the articles focusing on economic performance across all three levels, and $78 \%$ on the organizational level. MOR published, proportionally, more articles focusing on human welfare at the society level (17\%) compared with the top six English journals (0\%), and the three Chinese journals (1\%). 
Figure 3. Human welfare and performance focus in three leading Chinese journals (a five-year moving average) - all three levels combined

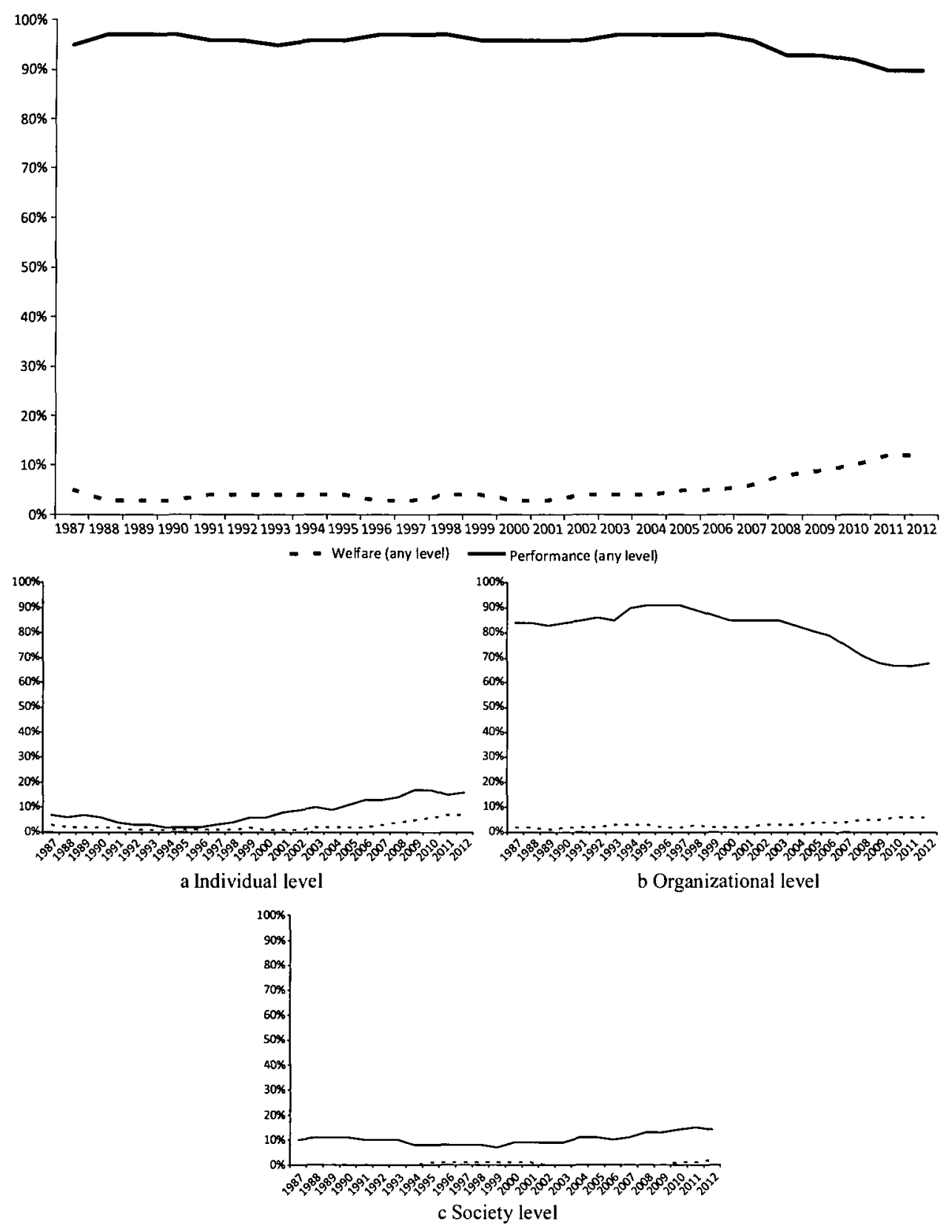

Figures 4 to 6 show the disciplinary perspectives reported in the articles. Figure 4 for the top six English journals and Figure 5 for $M O R$ correspond well with Walsh et al.'s (2003) Figure 4 for the $A M 7$ articles in the total number of articles using psychology, sociology, and economic perspectives over time. The Chinese journals (Figure 6), however, overwhelmingly focus on economic rather than psychology or 
Table 2. Comparing percentage (\%) of articles with major focus in three journal samples

\begin{tabular}{llccc}
\hline \hline Core focus & $\begin{array}{l}\text { 6 English } \\
\text { joumals } \\
\text { (26 Years) }\end{array}$ & $\begin{array}{l}\text { MOR } \\
\text { (8 years) }\end{array}$ & $\begin{array}{l}\text { 3 Chinese } \\
\text { joumals } \\
\text { (30 years) }\end{array}$ \\
\hline At any level & Economic performance & $82 \%$ & $69 \%$ & $94 \%$ \\
At individual level & Human welfare & $21 \%$ & $28 \%$ & $7 \%$ \\
At organizational level & Economic performance & $28 \%$ & $22 \%$ & $11 \%$ \\
At socicty level & Human welfare & $16 \%$ & $10 \%$ & $4 \%$ \\
& Economic performance & $50 \%$ & $38 \%$ & $78 \%$ \\
& Human welfare & $5 \%$ & $1 \%$ & $4 \%$ \\
& Economic performance & $5 \%$ & $8 \%$ & $11 \%$ \\
& Human welfare & $0 \%$ & $17 \%$ & $1 \%$ \\
\hline \hline
\end{tabular}

Figure 4. Disciplinary perspectives in six leading English journal (5-year moving average)

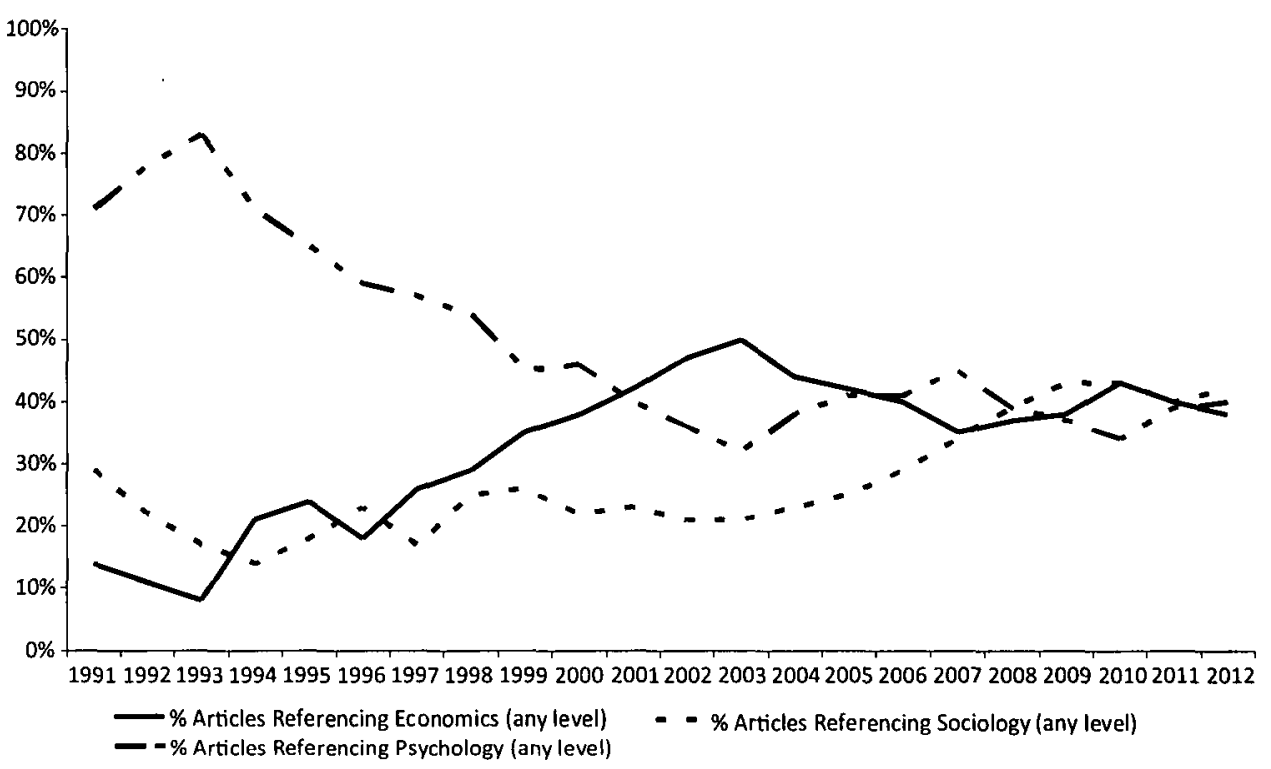

sociology perspectives. Table 3 provides the percentages of articles at each level of analysis and for all levels combined, across all years. In the six English journals and in $M O R$, the perspectives are more balanced: the English journals focus on economics in $37 \%$ of the articles, psychology in $43 \%$, and sociology in $34 \%$. MOR shows $26 \%$ economics focus, $36 \%$ psychology focus, and $32 \%$ sociology focus. However, the three Chinese journals predominantly focus on the economic perspective (89\%) over psychology (14\%) or sociology (7\%). At the organizational level, the English journals and MOR used a balance of economic (34\% and 22\%) and sociology perspectives $(24 \%$ and $20 \%$ ) but the Chinese journals employed primarily the economic perspective (75\%). 
Figure 5. Disciplinary perspectives in MOR (3-year moving average)

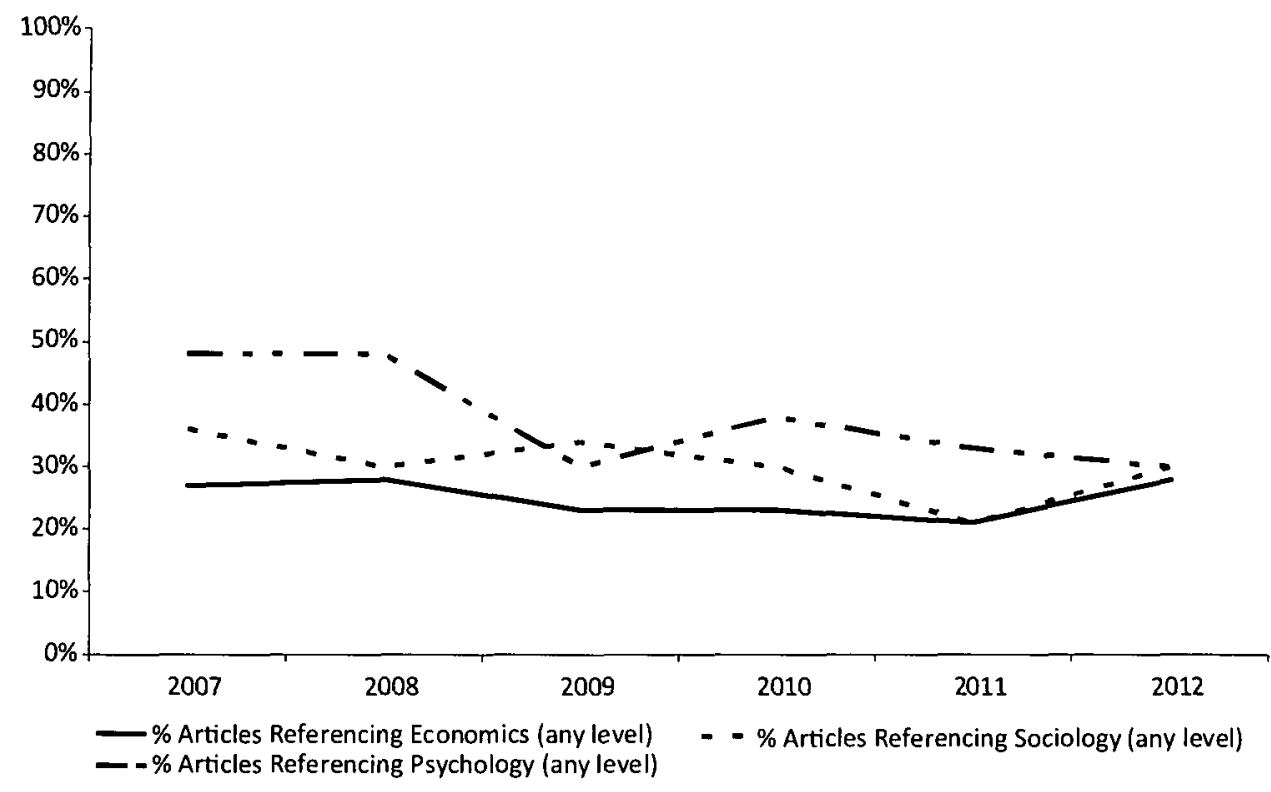

Figure 6. Disciplinary perspectives in three leading Chinese journal (5-year moving average)

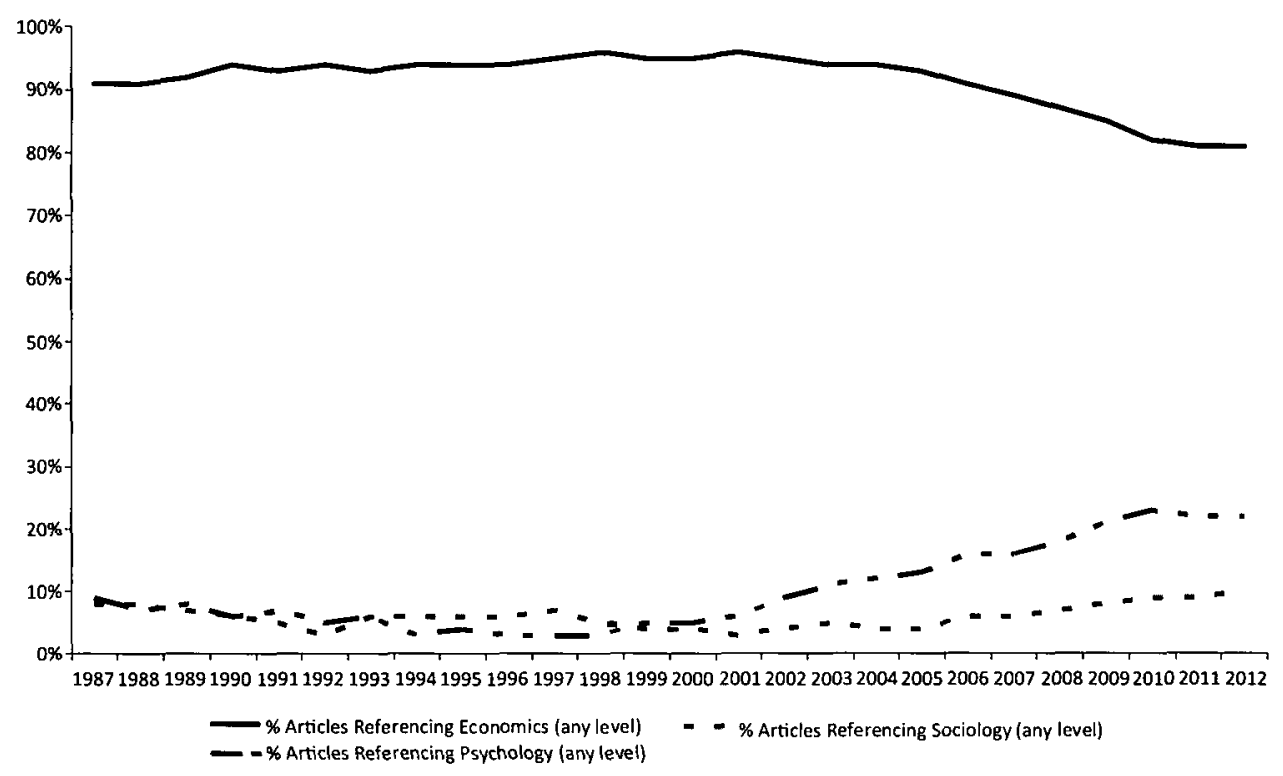

Clearly, the three Chinese journals diverged dramatically from the six leading English journals and $M O R$ regarding research focus and disciplinary perspective, with dramatic dominance of the economic perspective and a focus on economic performance. We next discuss why economics dominates in China. 
Table 3. Disciplinary perspective in three journal samples

\begin{tabular}{llccc}
\hline \hline & Perspective & $\begin{array}{l}6 \text { English } \\
\text { journals } \\
(26 \text { Years) }\end{array}$ & $\begin{array}{l}\text { MOR } \\
(8 \text { years })\end{array}$ & $\begin{array}{c}3 \text { Chinese } \\
\text { joumals } \\
\text { (30 years) }\end{array}$ \\
\hline At any level & Economics & $37 \%$ & $26 \%$ & $89 \%$ \\
& Psychology & $43 \%$ & $36 \%$ & $14 \%$ \\
At individual level & Sociology & $34 \%$ & $32 \%$ & $7 \%$ \\
& Economics & $1 \%$ & $0 \%$ & $8 \%$ \\
At organizational level & Psychology & $37 \%$ & $31 \%$ & $9 \%$ \\
& Sociology & $6 \%$ & $6 \%$ & $1 \%$ \\
& Economics & $34 \%$ & $22 \%$ & $75 \%$ \\
At society level & Psychology & $7 \%$ & $5 \%$ & $7 \%$ \\
& Sociology & $24 \%$ & $20 \%$ & $5 \%$ \\
& Economics & $2 \%$ & $4 \%$ & $11 \%$ \\
& Psychology & $0 \%$ & $0 \%$ & $0 \%$ \\
& Sociology & $4 \%$ & $6 \%$ & $2 \%$ \\
\hline \hline
\end{tabular}

\section{THE GURRENT STATUS OF INSTITUTIONAL BALANGE IN CHINA}

Since China adopted economic construction as its central task and opened to reform, China's economy has grown rapidly for more than three decades and has, since 2010, become the world's second largest economic force. China has gone from a centrally planned economy dominated by political logic to an imbalanced situation in which economic logic dominates the political, cultural, education, and health areas. Government, schools, universities, and hospitals have become parts of the economic system. They regard their services as market transactions, and use price mechanisms to maximize economic benefits. 'No matter whether the cat is black or white, if it catches mice, it's a good cat' (猫论) is the driving economic logic in Chinese society in the past 30 years (Harding, 1987: 58; Yu, 2008: 61).

In the interest of gross domestic production (GDP), central and local governments regard economic performance as their first important target. Local governments require that personnel at all levels, even schoolteachers, doctors, and police, meet assigned quotas of investments and economic tasks. The economic logic also prevails in education. Since the beginning of this century, China has industrialized education ${ }^{[1]}$. From 1997 to 2011 , the number of schools and total enrollments in free nine-year compulsory education including regular primary schools and junior secondary schools continually decreased, from 695,000 in 1997 to 295,300 in 2011 , a $57.5 \%$ decrease. Total enrollments decreased from 0.19 billion in 1997 to 0.15 billion in 2011, a $21.8 \%$ decrease. Since 2003, the Ministry of Education has issued data about non-state/private education showing that total enrollment in non-state or privately owned primary schools and secondary schools increased from 5.32 million in 2003 to 9.80 million in 2011 , an $84.3 \%$ increase. Non-state or 
private higher education institutions increased from 175 in 2003 to 676 in 2011, a $286 \%$ increase; and the total enrollments increased from 0.8 million in 2003 to 4.77 million in 2011 , a $488 \%$ increase. Large and rapid education industrialization seems to have transformed education into an economic transaction exchange. Education has its price, and prices differentiate quality of education.

Almost all Chinese colleges and universities recently adopted the reward system, akin to piecework. They pay faculty according to work quantity: the number of published papers, the rank of published journals, the number of theses read, and the number of students taught.

In a series of nationwide surveys (Fan, 2009), respondents attributed presentday Chinese ethics and morality to four influences in this order: (1) the market economy ( $40.1 \%$ of surveyed respondents reported that view), (2) socialist ideology $(25.1 \%)$, (3) Chinese tradition (20.2\%), and (4) Western influences (11.2\%). 'The cultural structure of ethics/morality in present-day Chinese society is an unstable four-sided trapezoid with the market economy morality as the main side, and the joint forces of the other three as the counter. The ethics/morality has the characteristics of economic determination' (Fan, 2009: 30). In the same study, Fan (2009) reported that $43.8 \%$ of the respondents agree that the espoused morality by the current Chinese society is 'unification of righteousness and interest, and ration guiding desire', while $49.2 \%$ agreed that 'forsaking good for the sake of gold' and 'selfish and individualism' characterize the Chinese society today. Further, 49.9\% consider virtue and happiness to be related, i.e., virtuous people are happy; but an equal proportion (49.4\%) indicate they are inconsistent or not correlated.

These results are not too surprising since research has shown (e.g., Inglehart, 1994) that developing economies emphasize materialistic values (economic perspective) and developed nations emphasize post-modern values, such as human welfare. China's focus on economic outcomes is consistent with high materialism. Economic status alone, however, may not be sufficient to explain the large discrepancy between economic performance focus and human welfare focus. The data based on the Academy Management Joumal show increasing emphasis on economic performance from $20 \%$ in 1963 to $35 \%$ in 1999 (even though the overall economy improved over these four decades). Human welfare focus increased from $20 \%$ in 1963 to about $32 \%$ in 1979 and decreased to $19 \%$ in 1999. Our data based on the leading six English journals (studies using Chinese data) show that the economic performance focus increased from 1991 to 2012, while the focus on human welfare decreased from 1991 to 2012. Both datasets suggest that interest in human welfare as a research topic lags interest in performance focus in the past five decades with the gap widening in recent years. This is true of both developed and developing economies. According to Inglehart's analysis, the rapid economic growth and the increasing standard of living in China over the 30 years should be reflected in more concern in human welfare. However, this is not reflected in the focus of management research published in the Chinese journals nor in the top English journals. The Chinese pattern also could 
be due to the slower development of the psychology and sociology disciplines in Chinese universities, relative to economics. This pattern reflects the greater and persistent focus on economics in this society. Interestingly, the Chinese government recognizes the danger of economic dominance by including societal harmony as a central focus of its national development plan ${ }^{[2]}$.

\section{CONGLUSION}

\section{Calling for Humanistic Scholarship}

Restoring humanism or compassion is feasible because individuals can take actions that change behaviors, beliefs, and values. For example, we can build volunteer centers in each community or organization, to encourage and coordinate volunteer activities. We can build conversation centers that promote attention to human conditions beyond economic needs, and to encourage participants to engage in heart-to-heart dialogue and to 'care' for each other (Tsui, 2013). We could modify educational experience in educational institutions from kindergarten to university levels. We can add more courses about human welfare, compassion, or justice, most urgently in business schools, which dominate China's current university education system ${ }^{[3]}$, and which produces most of China's future business leaders.

A recent study (Arrunada \& Vazquez, 2013) of the world's top 100 business schools, using graduates' salaries as a criterion, supported the value of a balanced MBA curriculum (including courses grounded in psychology and sociology) relative to a curriculum dominated by economics, which emphasizes analytical skills founded on the assumption of a single type of individuals, i.e., self-interested. The authors reasoned that a balanced curriculum with content and teaching methods that expose students to alternative models of human motivation, as discovered in psychology and sociology, complements the analytical skills of economic training and would increase the students' ability to discriminate transactional frameworks and better prepare them in management jobs.

As management and organization scholars, we can expand the topics of our studies to include issues that connect to human wellbeing. For example, studying the relationship between firm philanthropy and firm performance promotes economic logic; while studying the relationship between entrepreneurs' philanthropic behaviors and employees' happiness and health is humanistic research. To restore and strengthen humanism within the organizational system, we must engage in research that relies on psychology and sociology and not only economics as the disciplinary perspectives.

The analysis we did for this editorial suggested that Management and Organization Review is especially hospitable in featuring the fruit of humanistic scholarship. MOR already has published issues related to public and nonprofit sectors dedicated to advancing human welfare (Kojima, Choe, Ohtomo, \& Tsujinaka, 2012; Lan \& Galaskiewicz, 2012), to research ethics and caring for research participants 
(Schminke \& Ambrose, 2011; Tsui \& Galaskiewicz, 2011; Wright, 2011), to multiparty (government, nonprofit, business) collaboration for combatting health problems (Wang, 2012), and to showing how the Chinese form of capitalism can serve the greater social good (Lin, 2011). Management and Organization Review welcomes studies that focus on human welfare at all levels of analysis and that aspire to ensure a more humane and sustainable future for Chinese organizations.

\section{NOTES}

We thank Cai Yahua, You Shuyang, Zhao Kehan, Wang Yang, and Li Juexing for their assistance in the coding of the data from the journals. We thank Joseph Galaskiewicz, Kwok Leung, Arie Lewin, and Marshall Meyer for helpful comments on an earlier draft.

[1] These data come from the official website of the Ministry of Education of the People's Republic of China (http://www.moe.edu.cn/publicfiles/business/htmlfiles/moe/s6200/index.html).

[2] In the plenary session four of the $16^{\text {th }}$ Central Committee of the Communist Party of China (CPC) during September 16 to 19 of 2004, CPC declared 'constructing the harmonious socialism society' as the central task in the new century. And at the opening ceremony of the $18^{\text {th }} \mathrm{CPC}$ National Congress on November 8 of 2012, Chairman Hu Jintao proclaimed that the central target of CPC facing new challenges is to construct a harmonious socialism society with five joint civilization: economic, political, cultural, social, and ecological.

[3] In 2010, the total enrollments of business majors including management and economics accounts for $26 \%$ of total enrollments of whole higher education; while few universities had the business major at the beginning of 1980s. The graduates of all kinds of professional masters of education also increased rapidly; the proportion of all master graduates rises from $2.5 \%$ in 1997 to $30 \%$ in 2011 (http://www.moe.edu.cn/publicfiles/business/htmlfles/moe/s6200/index.html).

\section{REFERENCES}

Arrunada, B. \& Vazquez, X. H. 2013. How behavioral assumptions may affect management ability: A tentative earnings-based test. Management and Organization Review, 9(2): in press.

Boyer, E. L. 1996. The scholarship of engagement. Bulletin of the American Academy of Arts and Sciences, 49(7): 18-33.

Editor. 1958. Preface. Joumal of the Academy of Management, 1(I): 5-6.

Fan, H. 2009. Ethics and morality in China: The current situation and an analysis in terms of philosophy of mind. Social Sciences in China, 4: 27-42. (In Chinese). 樊浩 (2009), 当前中 国伦理道德状况及其精神哲学分析，中国社会科学，4: 27-42.

Friedman, M. 1970. The social responsibility of business is to increasc its profits. New York Times Magazine, September 13: http://doc.cat-v.org/economics/milton_friedman/business_ social_responsibility.

Harding, H. 1987. China's second revolution: Reform after Mao. Washington, D.C.: The Brookings Institution.

Inglehart, R. 1997. Modemization and post-modemization: Cultural, economic and political changes in 43 societies. Princeton, NJ: Princeton University Press.

Isaacson, W. 2008. Einstein: His life and universe. New York: Simon \& Schuster.

Jia, L. D., You, S. Y., \& Du, Y. Z. 2012, Chinese context and theoretical contributions to management and organization research: A three-decade review, Management and Organization Review, 8(1): 173-209.

Kojima, K., Choe, J. Ohtomo, T. \& Tsujinaka, Y, 2012. The corporate system and social organizations in China. Management and Organization Revieze, 8(3): 609-628.

Lan, G. Z., \& Galaskiewicz, J. 2012. Innovations in public and non-profit sector organizations in China. Management and Organization Revieze, 8(3): 491-506.

Lin, N. 2011. Capitalism in China: A centrally managed capitalism (CMC) and its future. Management and Organization Revieze, 7(1): 63-96. 
Schminke, M., \& Ambrose, M. L. 2011. Ethics and integrity in the publishing process: Myths, facts, and a roadmap. Management and Organization Review, 7(3): 397-406.

Sprecher, S., \& Fehr, B. 2005. Compassionate love for close others and humanity.Journal of Social and Personal Relationships, 22(5): 629-651.

Tsui, A. S. 2012. On compassion: Why should we care? Presidential address, Academy of Management mecting, August 5, 2012, Boston, MA.

Tsui, A. S. 2013. On compassionate scholarship: Why should we care? Academy of Management Review, 38(2): 167-181.

Tsui, A. S., \& Galaskiewicz, J. 2011 . Commitment to excellence: Upholding research integrity at Management and Organization Review. Management and Organization Revieze, 87(3): 389395.

Walsh, J. P. 2011. Presidential address - Embracing the sacred in our secular scholarly world. Academy of Management Review, 36: 215-234

Walsh, J. P., Weber, K., \& Margolis, J. D. 2003. Social issues and management: Our lost cause found. Joumal of Management, 29(6): 859-881.

Wang, M. 2012. Managing HIV/AIDS: Yunnan's government-driven, multi-sector partnership model. Management and Organization Review, 8(3): 535-557.

Wright, T. A. 2011 . And justice for all: Our research participants considered as valued stakeholders. Management and Organization Reviere, 7(3): 495-503.

Yu, Z. P. 2008. Spiritual accomplishments of the golden age: In memory of the 30 years of reform and opening up from the philosophical perspective. Joumal of Shanghai Jiao Tong University (Philosophy and Social Sciences), 16(6): 59-67. (In Chinese). 余治平 (2008), 黄金时代的 精神收获: 改革开放30年的哲学纪念, 上海交通大学学报(哲学社会科学版), 16(6): 59-67. 